\title{
GENITAL DUCTS IN SEVERAL SPECIES OF THE CYCLOPHORID GENUS LEPTOPOMA (MOLLUSCA, MESOGASTROPODA)
}

by

\author{
K. JONGES \\ Institute of Taxonomic Zoology (Zoölogisch Museum), \\ University of Amsterdam, The Netherlands
}

\begin{abstract}
In sixteen species of the cyclophorid genus Leptopoma female genital ducts were examined; in four species male genital ducts were examined as well. In the females, bursa copulatrix and receptaculum seminis were found to open into the mantle cavity, close to the longitudinal genital aperture. Bursa copulatrix and receptaculum seminis - when present - in cyclophorid snails, were hitherto described having openings into the pallial oviduct (Weber, Tielecke, Berry, Kasinathan).

A number of anatomical details of the female genital duct in Leptopoma are regarded useful diagnostic characters for the taxonomy of this group.
\end{abstract}

\section{INTRODUCTION}

Most terrestrial gastropods are pulmonates, numbering about 20,500 species. Land prosobranchs number about 3650 species which are confined mainly to the wet tropics. They are derived directly from families of marine snails and survived by changes in patterns of behaviour rather than by changes in structures. The major structural modification of the land prosobranchs is the loss of the gills, respiration taking place on the inner surface of the mantle.

There are both diotocardian and monotocardian land prosobranchs. The Helicinidae and Hydrocenidae are diotocardian, the Cyclophoridae, Pomatiasidae and Acmidae monotocardian. The present study deals with the anatomy of the genital ducts of several species of the genus Leptopoma belonging to the Cyclophoridae.

\section{THE MONOTOCARDIAN REPRODUCTIVE SYSTEM}

In the vast majority of monotocardian prosobranchs the sexes are separate. The gonad, testis or ovary, is found in the upper whorls of the visceral mass. Both male and female genital ducts extend along the columellar side of the visceral mass; in the mantle cavity they pass along the right side beneath the rectum.

In the female the genital duct opens into the mantle cavity; in the male it is continued through the penis which lies behind the right cephalic tentacle, or it opens within the mantle cavity into a seminal groove which passes along the right side of the head as far as the tip of the penis, the second condition being regarded the more primitive situation.

In both sexes the pallial part of the genital duct has thick glandular walls: in the male this part is called prostate gland; in the female this glandular duct can be divided in a posterior part which is called albumen gland, and an anterior part called capsule gland.

Two kinds of sperm pouches are communicating with the female genital duct: the bursa copulatrix which receives sperm and prostatic fluid, and the receptaculum seminis to which the sperm pass from the bursa.

\section{CYCLOPHORID GENITAL DUCTS}

Cyclophorid genitals have been described by Weber (1924), Tielecke (1940), Morton (1952), Berry (1964) and Kasinathan (1975). The descriptions of Weber (Cyclophorus ceylanicus (Sowerby, 1843)), Tielecke (species of Cyclophorus, Leptopoma and 16 more genera) and Kasinathan (Cyclophorus jerdoni (Benson, 1851) and 4 species of 3 other genera) gave an overall comparable picture.

The pallial part of the male genital duct opens via an anterior aperture into a seminal groove which runs up the side of the head to the tip of 
the penis. It consists of a hind portion extending backwards from the point of entry of the testis duct, and a fore portion leading across the mantle roof.

The pallial part of the female genital duct is described as a large glandular duct with an extensive lateral opening. Two elongated sacs extend posteriorly from their openings at the inner end of this duct. The larger of these is the bursa copulatrix. The smaller sac is the receptaculum seminis.

Weber (1924) did not mention the existence of a smaller sac in Cyclophorus ceylanicus, but she remarked that in one case the one big sac, which must have been the bursa, was containing the remains of a spermatophore. Kasinathan (1975) observed in living animals that spermatophores are manufactured in the pallial part of the male genital duct and are directly passed into the bursa copulatrix of the female during copulation.

In Murdochia pallidum (Hutton, 1883) the male genital duct is a narrow tube closed throughout its whole length, as far as the tip of the penis (Morton, 1952). Distinct sperm pouches communicating with the female genital duct are absent. A section of the ovarian duct functions as receptaculum seminis.

In Opisthostoma retrovertens Tomlin, 1938, a pouch-like receptaculum seminis is present, but a distinct bursa copulatrix is missing (Berry, 1964). The pallial part of the male genital duct opens anteriorly via a slit into a seminal groove.

\section{GENITAL DUCTS IN POMATIASIDAE AND ACMIDAE}

Creek $(1951,1953)$ described the genitals of Pomatias elegans (Müller, 1774) and Acme fusca (Montagu, 1803). In Acme fusca the male genital duct opens within the mantle cavity into a seminal groove which extends along the side of the head and the whole length of the penis. In the female a "common" duct links the bursa copulatrix, ovarian duct and the glandular pallial part of the genital duct with each other. Apart from connecting these parts it has an opening into the mantle cavity, thus permitting sperm to enter the bursa copulatrix during copulation. A pouch-like receptaculum seminis is missing. The pallial parts of both male and female genital ducts have a terminal opening.

In Pomatias elegans the male genital duct is a closed tube from the testis to the tip of the penis. In the female the ovarian duct opens into a pouchlike bursa copulatrix. Anteriorly, the bursa, which receives the penis during copulation, has a wide opening into the posterior end of the mantle cavity. The large and swollen pallial oviduct is open to the mantle cavity along the greater part of its ventral wall. A pouch-like receptaculum seminis is missing, but a section of the ovarian duct somewhat posterior to the bursa copulatrix functions as such.

\section{MATERIALS AND METHODS}

All specimens dissected are from the collection of the Institute of Taxonomic Zoology (Zoölogisch Museum) in Amsterdam and have been collected in the Indonesian Archipelago.

Of the female genital duct the pallial part alongside the rectum is figured with the foremost part of the ovarian duct. In all cases a figure is given of the columellar side of the pallial oviduct with the bursa copulatrix and receptaculum seminis lying in the plane of the paper. In most cases also a figure is given which shows the ventral aspect of the pallial oviduct with the posteriormost part of the albumen gland together with bursa, receptaculum and ovarian duct lying in the plarie of the paper.

\section{ABBREVIATIONS USED IN THE FIGURES}

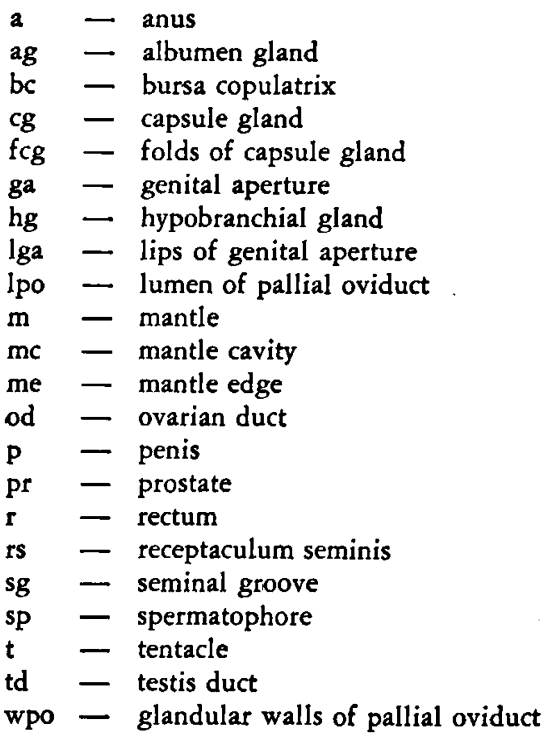


Leptopoma diplochilus Sykes, 1903

(Figs. 1-5)

Sykes, 1903: 66, pl. VI figs. 16-18 (type locality: "Waigiou"); Schepman, 1909: 197 (Waigeu I.: Piapis Bay); L. diplochilus + vars. erythrostoma, typica, maculata, unicolor Schepman, 1915: 28, fig. 7 (type localities of the four vars.: Waiu-waigé, along river Rabiai, Beo, Jefjum, Waimenil, Kaiawat, all on Waigeu I.); L. diplochilus: Van Benthem Jutting, 1963: 673 (West New Guinea: Arguni Bay, in Muka Arguni area; entrance of Arguni Bay, near village of Tongeronu).

Specimens dissected. Two ô ô (figs. 1-3, 4-5) and one $\%$, Waigeu I.: Beo (leg. De Beaufort, 1910).

Male genital duct. - From the testis which completely fills the apical whorls of the visceral mass, the straight testis duct leads forward to the posterior end of the mantle cavity. The prostate is a broad tube with thick glandular walls; it can be divided in a fore portion, which has an extensive lateral opening, and a hind portion. Anteriorly a seminal groove leads from the genital aperture to the tip of the penis. The penis is not a closed tube but a laterally folded structure inside which the seminal groove has its continuation.

Female genital duct. - The receptaculum seminis is quite large; it is nearly as long as the bursa copulatrix. Other details are congruent with those in the next species, $L$. gianellii, the female genital duct of which will be discussed more extensively.

\section{Leptopoma gianellii Tapparone Canefri, 1886} (Figs. 6-16)

L. gianellii + var. $\alpha$ Tapparone Canefri, 1886: 183, pl. II figs. 10-11 (type locality: "Katau e rive del fiume Fly, costa meridionale della Nuova Guinea"); Schepman, 1919: 177 (West New Guinea: Lorentz River, Digul River, Van der Sande River, Bivak I., Sabang, Resi Ridge, Van Weel's Camp); L. gianellii + forma $\alpha$ : Van Benthem Jutting, 1963: 668, 669 (West New Guinea: Sermovai River, Sorong, Digul River).

Specimens dissected. Two 9 क (figs. 6-13, 14-16), West New Guinea: Lorentz River (New Guinea Exped., 1909).

Female genital duct. - From the ovary in the upper whorls of the visceral mass, where it is embedded in tissue of the digestive gland, the straight ovarian duct leads forward to the mantle cavity. Before reaching the pallial oviduct it makes one complete coil. The pallial oviduct is a large glandular duct with an extensive lateral opening; pressed against the columellar side lie two sacs, the larger one of which is the bursa copulatrix and the smaller the receptaculum seminis. Posteriorly these sacs extend beyond the pallial oviduct and lie on the visceral mass.

Both the bursa and receptaculum open into the narrow space between the pallial oviduct and the columellar muscle, thus in fact into the mantle cavity; their openings are close to the lateral opening of the pallial oviduct.

In one of the females studied, the bursa contained a spermatophore (fig. 16; in situ: fig. 15). In the other female the bursa was filled with a vast quantity of a jelly-like substance which was for a part bulging out of it. In the second case probably a process of sperm mobilization by dissolution of one or more spermatophores was going on.

The free edges or "lips" of the genital aperture are somewhat thickened; by their shapes and positions they keep the genital aperture closed for the greater part.

On the ventral side of the pallial oviduct a tube runs alongside the rectum; anteriorly it opens into the pallial oviduct. It is not clear where this tube originates posteriorly and what function it has. This tube is indicated by an arrow in figs. 7 and 12.

The walls of the pallial oviduct become much convoluted anteriorly. The lumen of this part of the pallial oviduct can be dilated considerably when its walls are straightened out.

In the other species of Leptopoma studied, the structure of the female genital duct is basically the same as in L. gianellii. Therefore, in the discussion of the following species, remarks will be made only when differences appear in some details.

Leptopoma perlucidum (De Grateloup, 1840) (Figs. 17-23)

Cyclostoma perlucida De Grateloup, 1840: 442, pl. III fig. 13 (type locality: "Manille; les Iles Malaises"); Cyclostoma vitrea (non Cyclostoma vitreum Draparnaud, 1801) Lesson, 1831: 346, pl. XIII fig. 6 (type locality: "Ia Nouvelle-Gui- 

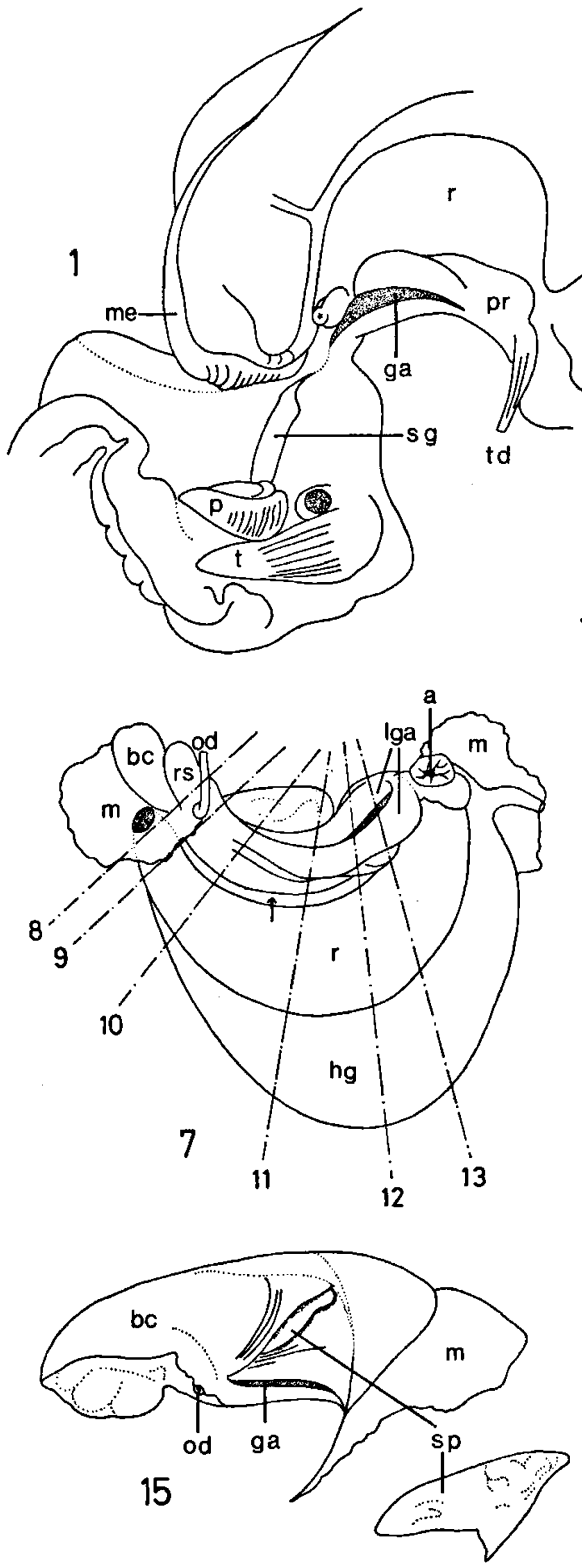

16

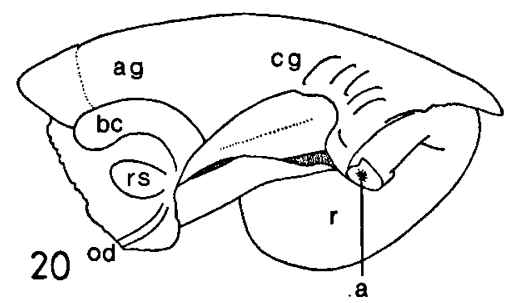



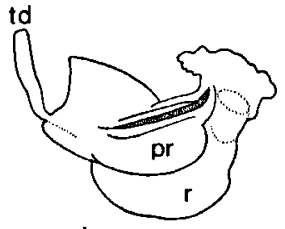

4


Figs. 1-5. Male genital ducts in Leptopoma diplocbilus: 1-3, 4-5 (Waigeu I.).

Figs. 6-23. Female genital ducts within the genus Leptopoma: 6-13, 14-16, L. gianellii (New Guinea); 17-19, L. perlucidum (Java); 20, L. perlucidum (Enggano I.); 21-23, L. perlucidum (Buru). 
née"); Cyclostoma vitreum: Mousson, 1849: 57, pl. VI fig. 4 (Java: Kurissan); Leptopoma vitreum: Von Martens, 1867: 145 (East Java: Wonosari, Banjuwangi); Van Benthem Jutting, 1948: 566, fig. 23 (Java: Tjisolok, Wijnkoopsbay, Udjung Genteng, Bandjar, Semarang, Gunung Kidul, Wlingi, Kali Mrawan, Malang); Leptopoma perlucidum: Van Benthem Jutting, 1963: 664 (West New Guinea: Jamur, Sorong, Klamono, Ajamaru, Merauke, Schouten I., Biak I., Owi I.)

Specimens dissected. Three $\$$ \% (figs. 17-19) and two $\hat{\delta} \hat{\delta}$, West Java: Wijnkoopsbay (leg. Lieftinck, 1934); one $\$$ (fig. 20), Enggano I.: Boeah-Boeah (leg. De Jong, 1936); one $\&$ (figs. 21-23), Buru: Wa Katin (leg. Toxopeus, 1921).

Male genital duct. - Like in L. diplochilus the prostate has an extensive lateral opening, and also in other regards the situation is the same as in that species.

Female genital duct. - In all females examined the posterior part of the pallial oviduct has a more or less rectangular shape compared with a more rounded shape in $L$. gianellii. In the females from Java the bursa is a small pouch comparable in size with the receptaculum (figs. 1719). In the female from Enggano I. (fig. 20) the bursa is twice as long as the receptaculum, and in the female from Buru (figs. 21-23) the bursa exceeds the size of the receptaculum many times.

\section{Leptopoma intermedium Von Martens, 1867} (Fig. 24)

L. vitreum 8 intermedium Von Martens, 1867: 144, pl. IV fig. 4 (type locality: "Amboina, Buru"); L. vitreum var. intermedium: Van Benthem Jutting, 1927: 10 (Buru: Leksula, plain of the mountain lake Rana, mountains surrounding lake Rana).

Specimen dissected. One $\$$ (fig. 24), Buru: surroundings of lake Rana (leg. Toxopeus, 1921).

Female genital duct. - Like in L. perlucidum the posterior part of the pallial oviduct has a rectangular shape.

\section{Leptopoma concinnum (Delessert, 1841)}

(Figs. 25-27)

Cyclostoma concinnum Delessert, 1841: pl. XXXVIII fig. 14 (type locality: unknown ("Habite...?")); Sowerby, 1843: 134, pl. XXIX figs. 223, 224 (Philippines: Bohol, Mindanao, Camiguing).
Specimens dissected. Three $q q$ (figs. 25-27) and two $\hat{\delta} \hat{\delta}$, Talaud Archipelago: Lirung on Salibabu I. (leg. Lam, 1926).

Male genital duct. - There are no diagnostic points of difference with $L$. diplochilus.

Fema le genit a l d u ct. - The bursa copulatrix is very large, extending far beyond the pallial oviduct posteriorly. The opening of the bursa lies far forward. The posterior part of the pallial oviduct has a rectangular shape.

\section{Leptopoma niasense Fulton, 1907}

(Figs. 28-30)

Fulton, 1907: 155, pl. X fig. 6 (type locality: "Nias Id."); Degner, 1928: 335 (Mentawei Is.); Van Benthem Jutting, 1959a: 184, 185, 187 (Satellite islands of Sumatra: Simalur I., Pulu Babi, Nias I., Mentawei Is.).

S pecimen dissected. One $\$$ (figs. 28-30), Nias I.: wood and ladangs near cave Tegindawa (leg. Van der Meer Mohr, 1931).

Female genit a l duct. - The bursa copulatrix extends far beyond the pallial oviduct posteriorly; it contained a spermatophore (fig. 29).

\section{Leptopoma minus Von Martens, 1867}

(Figs. 31-32)

L. vitreum \& minus Von Martens, 1867: 144, pl. IV fig. 6 (type locality: "Amboina"); L. vitreum var. minus: Van Benthem Jutting, 1928: 154 (Sumba: Laora); L. vitreum minus: Zilch, 1954: 145 (Ambon).

Specimen dissected. One + (figs. 31-32), Ambon, in secondary wood (leg. Lieftinck, 1949).

\section{Leptopoma pulicarium Pfeiffer, 1861}

(Figs. 33-36)

Pfeiffer, 1861: 29, pl. III fig. 7 (type locality: "Batchian"); Reeve, 1862: Conch. Icon. 13, Leptopoma, pl. V fig. 28 (Batjan); Kobelt, 1901: 444, pl. LV fig. 7 (Batjan).

Specimens dissected. One 9 (figs. 33-35), Batjan: Wajaua (leg. Wegner, 1953); one $\$$ (fig. 36), Obi: near Telaga Obi (leg. Wegner, 1953). 


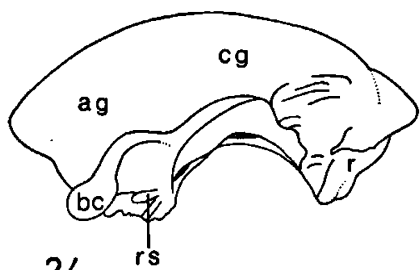

24



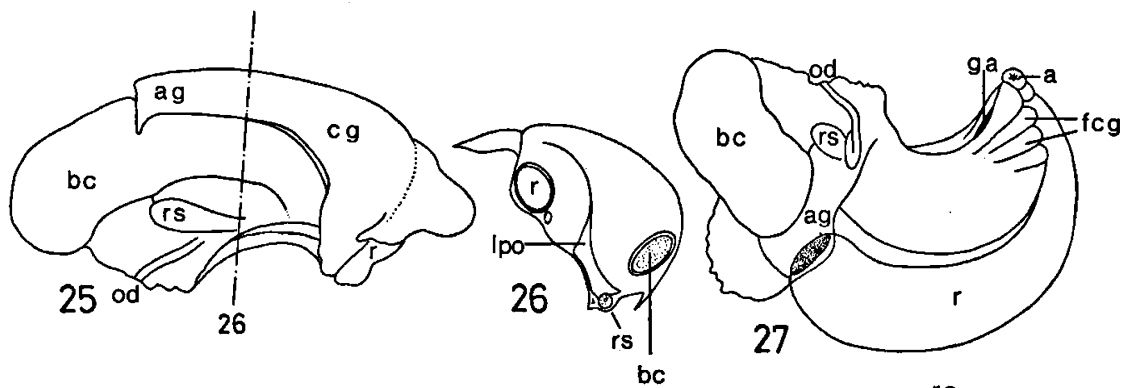
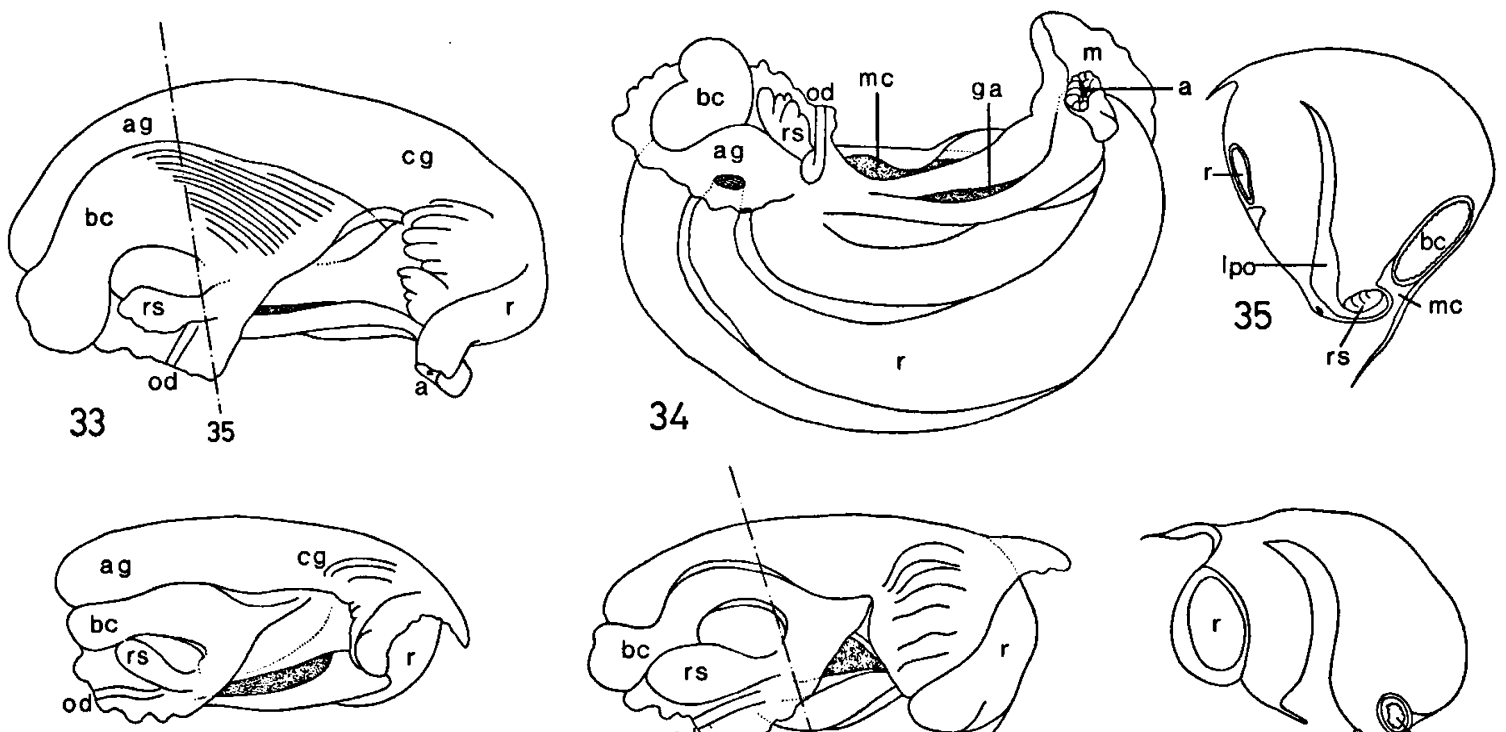

36
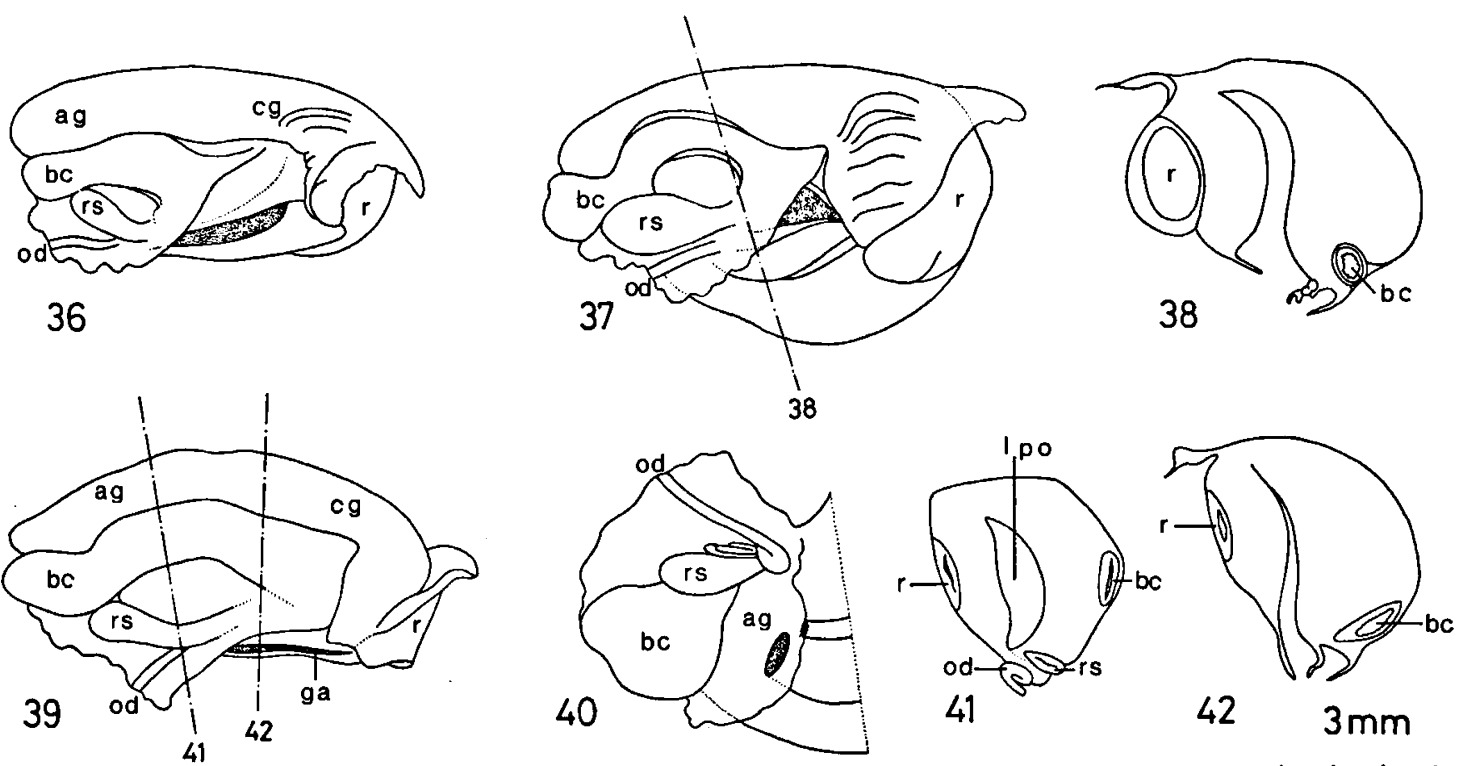

Figs. 24-42. Female genital ducts within the genus Leptopoma: 24, L. intermedium (Buru); 25-27, L. concinnum (Talaud Archipelago); 28-30, L. niasense (Nias I.); 31-32, L. minus (Ambon); 33-35, L. pulicarium (Batjan); $36, L$. pulicarium (Obi); 37-38, L. massena (Halmahera); 39-42, L. bicolor (Ceram). 
Leptopoma massena (Lesson, 1831) (Figs. 37-38)

Cyclostoma massena Lesson, 1831: 346, pl. XIII fig. 7 (type locality: "havre de Doréry, à la Nouvelle-Guinée"); Leptopoma massenae: Tapparone Canefri, 1878: 274 (Port Dorey); id., 1883: 261 (New Guinea); id., 1886: 171 (West New Guinea); $L$. callicbloros + var. $\alpha$ Tapparone Canefri, 1886: 178, pl. II figs. 16-17 (type locality: "Ramoi, di fronte all' isoletta Sorong"); L. crenilabre Strubell \& Boettger in Strubell, 1892: 49 (type locality: "Halmahera"); Kobelt, 1897: 23, pl. IV fig. 7 (Halmahera); L. callichloros: Smith, 1897: 415 (New Guinea: Kapaur); L. massenae: Fulton, 1899: 213 (Batjan); L. crenilabre: Kobelt, 1901: 412, pl. LII figs. 1.2 (Halmahera); Zilch, 1954: 142, pl. XIV fig. 15 (Halmahera; Halmahera: Patani); Van Benthem Jutting, 1959b: 40 (Halmahera: Ake Lamo on the Goal Plains, Mt. Sembilan, Toliwang); L. massena massena: Van Benthem Jutting, 1963: 666 (many localities in West New Guinea).

Specimen dissected. One $\$$ (figs. 37-38), Halmahera: Ake Lamo on the Goal Plains ("Molukken Exped.", 1951).

\section{Leptopoma bicolor (Pfeiffer, 1852)}

(Figs. 39-42)

Cyclostoma bicolor Pfeiffer, 1852: 145, pl. XIII fig. 9 ("Locality unknown"); Pfeiffer, 1853: 374, pl. XLVIII figs. 25-27 (locality unknown); Leptopoma bicolor: Reeve, 1862: Conch. Icon. 13, Leptopoma, pl. II fig. 13 (locality unknown); L. vitreum $\gamma$ latilabre Von Martens, 1867: 144, pl. IV fig. 5 (type locality: "Ceram bei Wahai"); L. latilabre: Von Moellendorff, 1897: 32 (Ceram: Wahai); Kobelt, 1906: 451, pl. LVI figs. 1-2 (Ceram); Van Benthem Jutting, 1953: 284 (Ambon); Zilch, 1954: 150, pl. XVI fig. 42 (Ceram: Wahai); L. perlucidum forma latilabre: Van Benthem Jutting, 1959b: 44 (Halmahera, Goal Plains).

Specimens dissected. One $\$$ (figs. 39-42), West Ceram: Honitetoe (leg. De Beaufort, 1910); one \%, Ceram: surroundings of Wahai (collector unknown).

\section{Leptopoma sp.}

(Figs. 43-46)

Specimen dis sected. One 9 (figs. 43-46), Morotai I.: Goegoeti (leg. Lam, 1926).

The five specimens of the lot have a thin translucent whitish shell with eight extremely fine white spiral bands at the places of the very weak spiral keels. The shells resemble most those of L. cinctellum Pfeiffer, 1861; differences are a larger size of the shells and a relatively larger size of the shell apertures, the last whorl being more globose,
F e ma le gen it a l d u ct. - The bursa copulatrix, extending far beyond the pallial oviduct posteriorly, is very broad.

\section{Leptopoma papuanum Dohrn, 1862}

(Figs. 47-55)

Dohrn, 1862: 181 (type locality: "In Nova Guinea"); $L$. aurantiellum + vars. $\alpha$ and $\beta$ Tapparone Canefri, 1886: 176, pl. II figs. 4-5 (type locality: "Kulo-Kadi presso Tangion Bair; Tangion Bair, costa occidentale della Nuova Guinea"); L. papuanum: Van Benthem Jutting, 1958b: 303 (Misool: $10 \mathrm{~km} \mathrm{~N}$. of Lelintah, environs of Fakal, between Waigama and Waima, environs of Solal, rainforest near Gam, village gardens near Lenmalas); Van Benthem Jutting, 1963: 667 (many localities in West New Guinea).

Specimens dissected. One 9 (figs. 47-50), West New Guinea: Pionierbivak on the Mamberamo River (Dutch New Guinea Exped., 1920); two $q$ \% (fig. 51 and figs. 5355, a specimen with a dark peristome), N.W. Miscol: between Waigama and Waima (leg. Lieftinck, 1948); one $q$ (fig. 52), N. Misool: surroundings of Solal (leg. Lieftinck, 1948).

Leptopoma melanostoma (Petit de la Saussaye, 1841)

(Figs. 56-58)

Cyclostoma melanostoma Petit de la Saussaye, 1841: 308 (type locality: "Nouvelle Guinée"); Pfeiffer, 1846: 173, pl. XXV figs. 12-15 (New Guinea); Leptopoma melanostoma + var. $\beta$ Tapparone Canefri, 1883: 258 (type locality of the var. $\beta$ : "Is. Aru, Vokan"); L. nigrilabrum Tapparone Canefri, 1886: 182, pl. II figs. 12-13 (type locality: "Kapaor, costa occidentale della Nuova Guinea"); L. melanostoma + var. rufolabiata: Schepman, 1919: 177 (West New Guinea: Moaif); L. vitreum melanostomum: Boettger, 1922: 396, pl. XXII figs. 28-29 (Aru Is.); Zilch, 1954: 146 (Aru Is.: Seltutti, Kobroor); L. melanostoma + forma $\beta+$ forma rufolabiata: Van Benthem Jutting, 1963: 669, 670 (many localities in West New Guinea).

Specimen dissected. One $\$$ (figs. 56-58), S.W. New Guinea: Aen Dua (leg. Lundquist, 1941).

Female genital duct. - The receptaculum seminis is a relative large sac, exceeding the bursa copulatrix in length.

\section{Leptopoma moussoni Von Martens, 1865}

(Figs. 59-61)

Von Martens, 1865: 52 (type locality: "Timor bei Kupang"); Rensch, 1933: 495 (Sumba: Mao Marru); L. moussoni moussoni: Zilch, 1954: 151, pl. XVI fig. 45 (Timor: Kupang); 



52
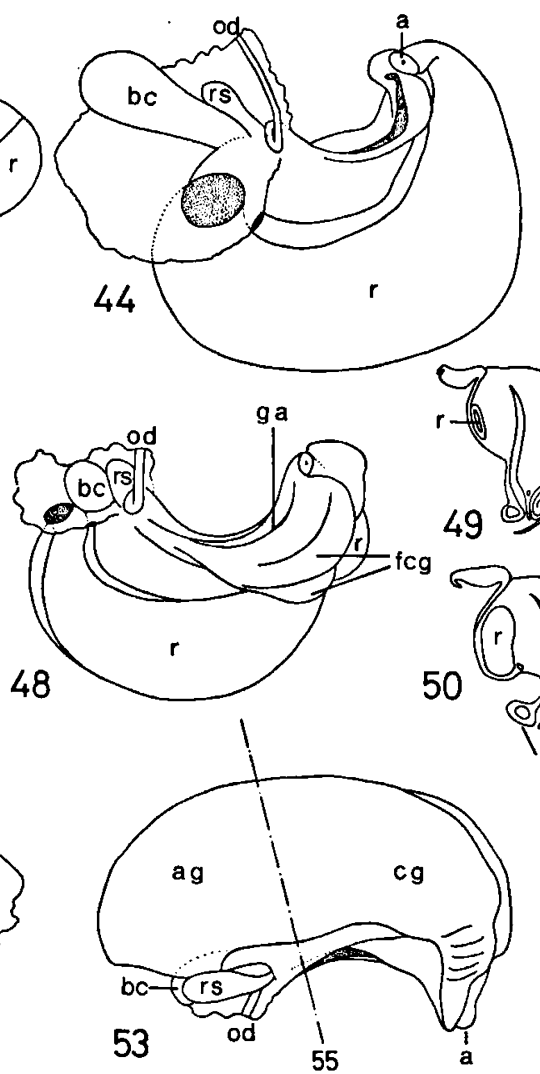
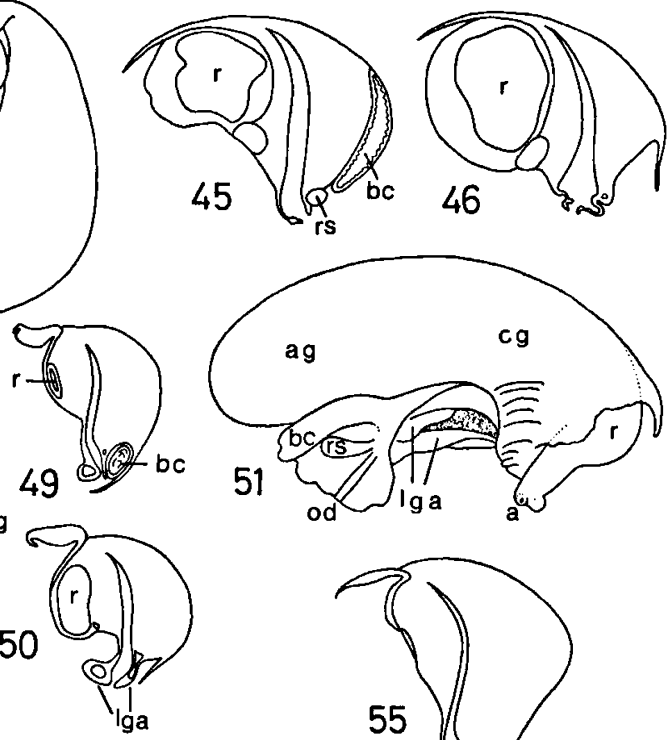

55
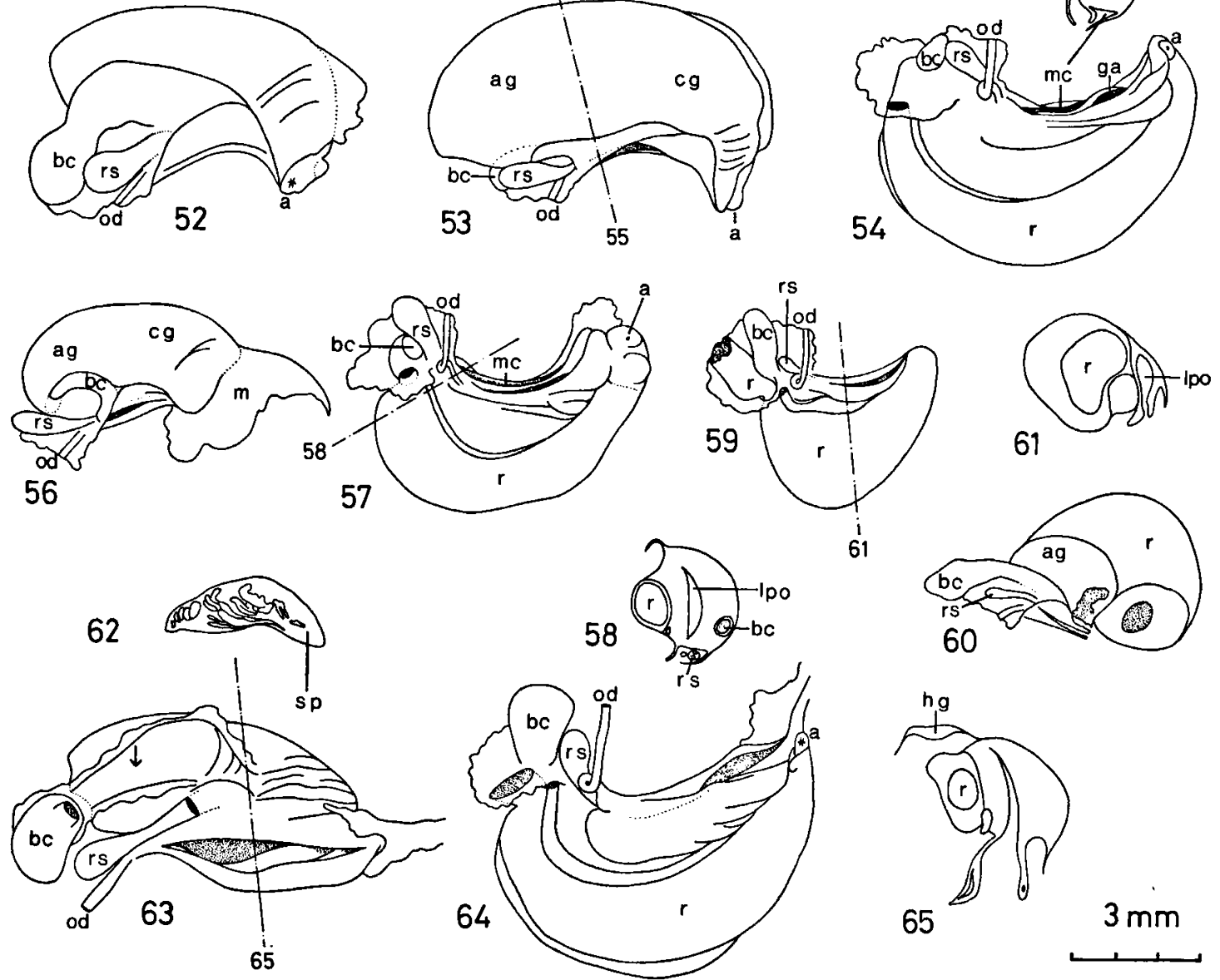

61

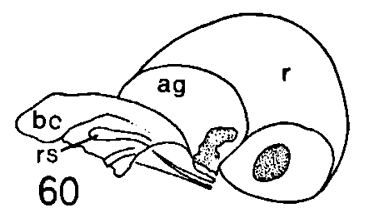

Figs. 43-65. Female genital ducts within the genus Leptopoma: 43-46, Leptopoma sp. (Morotai 1.); 47-50, L. papuanum (New Guinea); 51, 52, 53.55, L. papuanum (Misool); 56-58, L. melanostoma (New Guinea); 59-61, L. moussoni (Sumba); 62-65, L. fulgurans (Batjan). 
L. moussoni: Van Benthem Jutting, 1958a: 91 (East Sumba: Prai Jawang, Rende Wai, Baing, Mao Marru; West Sumba: Waimangura; Central Sumba: Langgaliru).

Specimens dissected. Two $\$$ (figs. 59-61), East Sumba: edge of wood near Wai Lekabe Valley (Sumba Exped., 1949).

Leptopoma fulgurans Dautzenberg, 1902 (Figs. 62-65)

Dautzenberg, 1902: 3, figs. 6 (type locality: "Obi"); id., 1903: 15, pl. I figs. 10-11 (Obi); Van Benthem Jutting, 1959b: 42 (Batjan; Batjan near Wajaua).

Specimens dissected. Two $\$$ ㅇ (figs. 62-65), Batjan: Wajaua (leg. Wegner, 1953).

Female genital duct. - The bursa copulatrix shows a particularity. The posterior part of it is in fact a separate pouch which opens via an outlet into a "corridor". This corridor (indicated by an arrow in fig. 63) opens at the normal position against the wall of the pallial oviduct near the opening of the receptaculum seminis.

In one of the females examined the corridor contained a spermatophore (fig. 62); in the other female the posterior pouch was completely filled with a jelly-like substance of which a thin strand was present in the corridor as well.

\section{Leptopoma decipiens Pfeiffer, 1861 (not figured)}

Pfeiffer, 1861: 29, pl. III fig. 10 (type locality: "Batchian"); Reeve, 1862: Conch. Icon. 13, Leptopoma, pl. IV fig. 20 (Batjan).

Specimens dissected. One $\hat{o}$ and one $\%$, Obi: Anggai (leg. Wegner, 1953).

Male genital duct. - There are nodiagnostic points of difference with $L$. diplochilus.

F e m a l e ge n it a l d u ct. - The long slender bursa copulatrix extends far beyond the pallial oviduct posteriorly. The left lip of the genital aperture is laterally folded, forming a sort of tube.

\section{DISCUSSION}

According to descriptions of cyclophorid female genitals by Weber (1924), Tielecke (1940), Ber- ry (1964) and Kasinathan (1975), bursa copulatrix and receptaculum seminis open into the pallial oviduct. Female genitals in Leptopoma are dissimilar in this regard. In all species of Leptopoma discussed in this paper, bursa copulatrix and receptaculum seminis were found to open against the wall of the pallial oviduct into the mantle cavity; their openings are near the longitudinal genital aperture.

In Pomatias elegans and Acme fusca a pouchlike receptaculum seminis is missing, a part of the ovarian duct functioning as such. In both species, however, a pouch-like bursa copulatrix is found which is situated posteriorly (Creek, 1951, 1953). In Pomatias elegans the bursa, which receives the penis during copulation, has a wide opening into the posterior end of the mantle cavity. In Acme fusca a "common" duct, linking ovarian duct and bursa copulatrix with the pallial oviduct, has an opening into the mantle cavity as well, which allows sperm to enter directly into the bursa during copulation. Thus, in having separate openings into the mantle cavity for the copulatory and egg-producing parts, the female genital system in species of Leptopoma resembles that in Pomatias elegans and Acme fusca.

The occurrence of spermatophores in members of the Cyclophoridae was already mentioned by Weber (1924) and Kasinathan (1975). In the bursa copulatrix of three female specimens of $L e p$ topoma spermatophores were found (figs. 16, 29, 62).

In male specimens of Leptopoma the prostate has, like the pallial oviduct, an elongated lateral opening, while in other cyclophorid snails, described in the literature, the prostates have an anterior opening. Probably the relatively large size of the spermatophores makes an elongated lateral opening necessary.

Kasinathan (1975) mentioned sizes of the spherical egg capsules of the cyclophorid species he studied.

The diameter of these egg capsules is large enough to explain the large lateral opening of the pallial oviduct in these species. In Pomatias elegans the female genital aperture is a ventral slit comparable to the elongated lateral opening of the pallial oviduct in Leptopoma, and the great extent 
of it may be correlated also with the expulsion of the large egg capsules which, when fully formed, completely fill the pallial oviduct (Creek, 1951).

Basically the structure of the female genital duct is the same in the 16 species of Leptopoma studied; however, in some details differences can be recognized. These details, which may be regarded useful diagnostic characters, are: (1) the shape of the posterior part of the pallial oviduct - the albumen gland - which is rounded or rectangular; (2) the proportions of the sizes of bursa copulatrix and receptaculum seminis; (3) the form of the lips of the genital aperture (in most species they are thin; in a number of species however, the left lip in particular is thickened, being laterally folded or over a part of its length even completely tubelike).

A particular condition of the bursa copulatrix is found in L. fulgurans. In this species the posterior part of the bursa copulatrix is a separate pouch which opens via an outlet into a "corridor". This condition might have some implications on the generic level.

Comparison of male genital ducts in four species of Leptopoma did not reveal any diagnostic points of difference. Therefore, morphologic characters of the male genital duct in Leptopoma seem less appropriate for the taxonomy of this group. Shapes and sizes of spermatophores, manufactured in the prostate, are probably good diagnostic characters.

\section{ACKNOWLEDGEMENTS}

I ain grateful to Dr. H. E. Coomans and Mr. R. G. Moolenbeek for the facilities offered at the department of Malacology of the Institute of Taxonomic Zoolog;. Mr. J. Zaagman of the same Institute is kindly thanked for his assistance durine the preparation of the figures.

\section{REFERENCES}

Benthem Jutting, W. S. S. van, 1927. Fauna Buruana, Mollusca. Treubia, 7: 1-33, pls. I-II.

-, 1928. Non-marine Mollusca of Sumba. Treubia, 10: 153-162.

- 1948. Critical revision of the Javanese operculate landshells of the families Hydrocenidae, Helicinidae, $\mathrm{Cy}$ clophoridae, Pupinidae and Cochlostomatidae. Treubia, 19: $539-604$.

- 1953. Annotated list of the non-marine Mollusca of the Moluccan islands Ambon, Haruku, Saparua and Nusa. Laut. Treubia, 22: 275-318.
- 1958a. Landmollusken von Sumba. Verh. naturf. Ges. Basel, 69: 90-117, pls. I-II.

_ 1958b. Non-marine Mollusca of the island of Misool. Nova Guinea, (N.S.) 9: 293-388.

- 1959a. Catalogue of the non-marine Mollusca of Sumatra and of its satellite islands. Beaufortia, 7: 41-191, pls. I-II.

_. 1959b. Non-marine Mollusca of the North Moluccan islands Halmahera, Ternate, Batjan and Obi. Treubia, 25: $25-87$.

- 1963. Non-marine Mollusca of West New Guinea. Part 2, operculate land shells. Nova Guinea, (Zool.) 23: 653-726, pls. XXVII-XXX.

BERRY, A. J., 1964. The reproduction of the minute cyclophorid snail Opisthostoma (Plectostoma) retrovertens from a Malayan limestone hill. Proc. zool. Soc. Lond., 142: $655-663$.

Boettger, C. R., 1922. Die Landschneckenfauna der Aruund Kei-Inseln. Abh. senckenb. naturforsch. Ges., 35: 3.55-417, pls. XXI-XXIII.

Creek, G. A., 1951. The reproductive system and embryology of the snail Pomatias elegans (Müller). Proc. malac. Soc. Lond., 21 : $599-640$.

- 1953 . The morphology of Acme fusca (Montagu) with special reference to the genital system. Proc. malac. Soc. Lond., 29: 228-240.

Dautzenberg, PH., 1902. Description de mollusques nouveaux provenant de l'île Obi (Moluques). Naturaliste, 1902: $247-248$.

_- 1903. Contribution à la faune malacologique terrestre et d'eau douce des îles Obi et Iolo. J. Conch. Paris, 51: 5-20, pl. I.

Degner, E., 1928. Binnen-Mollusken von den MentaweiInseln. Treubia, 10: 319-390.

Delessert, B., 1841. Recueil de coquilles décrites par Lamarck dans son histoire naturelle des animaux sans vertèbres et non encore figurées: $1-99$, pls I-XL (J. Rothschild, Paris).

DoHrN, H., 1862. Descriptions of new operculated land shells. Proc. zool. Soc. Lond., 1862: 181-184.

Fulton, H. C., 1899. A list of the species of landmollusca collected by Mr. W. Doherty in the Malay Archipelago; with descriptions of some supposed new species and varieties. Proc. malac. Soc. Lond., 3: 212-219, pl. XI.

- 1907. Descriptions of new species of Trochomorpha, Cochlostyla, Amphidromus, Bulimulus, Drymaeus, Placostylus, Stenogyra, Leptopoma, Cyclophorus, Cyclotus, Alycaeus. Ann. Mag. nat. Hist., (7) 19: 149-157, pls. IX-X.

Grateloup, J. P. S. DE, 1840. Mémoire sur plusieurs espèces de coquilles nouvelles ou peu connues de mollusques exotiques, vivants, terrestres, fluviatiles et marins. Act. Soc. linn. Bordeaux, 11: $389-455$, pls. I-IV.

Kasinathan, R., 1975. Some studies of five cyclophorid snails from peninsular India. Proc. malac. Soc. Lond., 41: $379-394$.

Kobelt, W., 1897. Land- und Süsswasserkonchylien. Abh. senckenb. naturforsch. Ges., 24: 19-92.

-, 1901-1906. Die gedeckelten Lungenschnecken (Cyclostomacea). In: Martini \& Chemnitz, Syst. Conch. Cab., 1 (19, N.F.): 401-488, pls. LI-LXI (Bauer und Raspe, Nürnberg).

Lesson, R. P., 1831. Mollusca. In: Voyage autour du monde. .. sur la Corvette "La Coquille" ... 1822-1825, 
2 (1): 1-471, Moll. pls. I-XVI (A. Bertrand, Paris).

Martens, E. von, 1865. Über neue Landschnecken aus Ostindien und über zwei Seesterne von Costa Rica. Mber. dt. Akad. Wiss. Berl., 1865: 51-59.

—, 1867. Die Landschnecken. In: Die Preussische Expedition nach Ost Asien, (Zool.) 2: i-ix, 1-447, pls. I-XXII (Königlichen geheimen Ober-Hofbuchdruckerei (R. v. Decker), Berlin).

MOELlendorfF, O. voN, 1897. Diagnosen neuer und kritischer Landdeckelschnecken. Nachr.-Bl. dt. malakozool. Ges., 29: 31-45.

Morton, J. E., 1952. A preliminary study of the land operculate Murchodia pallidum (Cyclophoridae, Mesogastropoda). Trans. R. Soc. N. Z., 80: 69-79.

Mousson, A., 1849. Die Land und Süsswasser-Mollusken von Java: i-iv, 1-126, pls. I-XXII (F. Schultess, Zürich).

Petit de la Saussaye, S., 1841. Description d'une nouvelle espèce de Cyclostome. Revue zool. (Soc. Cuv.), 4: 308309.

Pfeiffer, L., 1846-1853. Die gedeckelten Lungenschnecken (Helicinacea et Cyclostomacea). In: Martini \& Chemnitz, Syst. Conch. Cab., 1 (19): 1.400, pls. A, I-L (Bauer und Raspe, Nürnberg).

-, 1852. Descriptions of fourteen new species of landshells, from the collection of Hugh Cuming, Esq. Proc. zool. Soc. Lond., 20: 135-147, pl. XIII.

-, 1861 . Descriptions of forty-seven new species of landshells, from the collection of $\mathrm{H}$. Cuming, Esq. Proc. zool. Soc. Lond., 1861: 20-29, pls. II-III.

REEVE, L. A., 1862. Monograph of the genus Leptopoma. Conchologia Iconica, 13: pls. I.VII (L. Reeve \& co., London).

RensCH, B., 1933. Zur Landschneckenfauna von Sumba. Sber. Ges. naturf. Freunde Berl., 1933: 492-508.

Schepman, M. M., 1909. The Prosobranchia of the SibogaExpedition. Part II: Taenioglossa and Ptenoglossa. Si- boga Exped., Monogr. XLIX 1b (= livr. 43): 109-232, pls. X-XVI.

- 1915. On a collection of land and freshwater and marine Mollusca from Waigeu, Ceram, Puluh Weh and Java. Bijdr. Dierk., 20: 17-33.

- 1919. On a collection of land, freshwater and marine Mollusca. Nova Guinea, (Zool.) 13: 155-196, pls. IV. VIII.

SMITH, E. A., 1897. On a collection of land-shells from New Guinea. Ann. Mag. nat. Hist., 20: 409-420, pl. IX.

SOWERBY, G. B., 1843. Monograph of the genus Cyclostoma. Thesaurus Conchyliorum, 1: 89-156, pls. XXIII-XXXI (Sowerby, London).

STRUBELL, B., 1892. Landschnecken aus Halmahera. Nachr.Bl. dt. malakozool. Ges., 24: 41-50.

SYKES, E. R., 1903. Descriptions of new landshells from the Austro-Malayan region. J. Malac., 10: 64-67, pl. VI.

TAPparone Canefri, C., 1878. Catalogue des coquilles rapportées de la Nouvelle-Guinée par M. Raffray. Bull. Soc. zool. Fr., 3: 244-277, pl. VI.

- 1883. Fauna malacologica della Nuova Guinea e delle isole adiacenti. Annali Mus. civ. Stor. nat. Giacomo Doria, 19: 1-313, pls. I-XI.

_ 1886. Fauna malacologica della Nuova Guinea e delle isole adiacenti. Suppl. I. Annali Mus. civ. Stor. nat. Giacomo Doria, (2) 4: 129-200, pl. I.

Tielecke, H., 1940. Anatomie, Phylogenie und Tiergeographie der Cyclophoriden. Arch. Naturgesch., (N. F.) 9: 317-371.

Weber, L., 1924. Die Mantel- und Geschlechtsorgane von Cyclophorus ceylanicus (Sowerby). Jena. Z. Naturw., 60: $397-438$.

ZILCH, A., 1954. Die Typen und Typoide des Natur-Museums Senckenberg, 13: Mollusca, Cyclophoridae, Cyclophorinae-Cyclophoreae (1). Arch. Molluskenk., 83: 141157, pls. XIII-XVI. 